\title{
Acute haemorrhagic oedema of infancy
}

\author{
Cristiana Carvalho, ${ }^{1}$ Gustavo Januário, ${ }^{2}$ Paulo Maia ${ }^{1}$
}

${ }^{1}$ Pediatric department, Centro Hospitalar de

Leiria-Pombal, Leiria, Portugal

${ }^{2}$ Pediatric Department, Hospital Pediátrico de Coimbra

Coimbra, Portugal

\section{Correspondence to}

Dr Cristiana Carvalho,

cristiana.mafalda@gmail.com
To cite: Carvalho $C$ Januário G, Maia P. BMJ Case Rep Published online: [please include Day Month Yearl doi:10.1136/bcr-2012008145

\section{DESCRIPTION}

We present a previously healthy 9-month-old girl which presented to our emergency department with coryzal-like symptoms, a 3-day history of fever and rigours and large purpuric plaques with irregular, annular and targetoid shapes, located on the face, hands and perineum and sparing the trunk, which had appeared in the previous $24 \mathrm{~h}$ and were still progressing (figures 1 and 2). There was bilateral oedema of the hands and feet. She had stopped amoxicilin 4 days earlier for acute otitis media and the recent vaccination history was not stated. Upon examination, she appeared well and she was normotensive. Her urinalysis was normal as were her full blood count and clotting screening. The $\mathrm{C}$ reactive protein was $5.3 \mathrm{mg} / \mathrm{l}$ and her blood culture was negative. A dermatologist's consultation confirmed the diagnosis of acute haemorrhagic oedema of infancy (AHEI).

The child received only symptomatic treatment and there was regression of the lesions in 2 weeks.

AHEI is a leucocytoclastic vasculitis, involving the small blood vessels in the dermis. It typically occurs in children between the ages of 4 months2 years and is self-limited. Its aetiology remains unknown, although some consider AHEI an immune complex-mediated disease. ${ }^{12}$

The classical features of AHEI are fever, oedema and rosette-shaped, annular-shaped or targetoidshaped purpura affecting the face, ears and extremities, in a well-appearing child. The onset is sudden and the oedema may be painful. Systemic symptoms such as abdominal pain, gastrointestinal bleeding, arthritis and nephritis are rarely reported. ${ }^{2}$

The differential diagnosis of AHEI includes Hennoch-Scönlein purpura, menigoccocemia, hypersensitivity vasculitis, Kawasaki disease, drug eruption, urticaria, malignancies and child abuse.

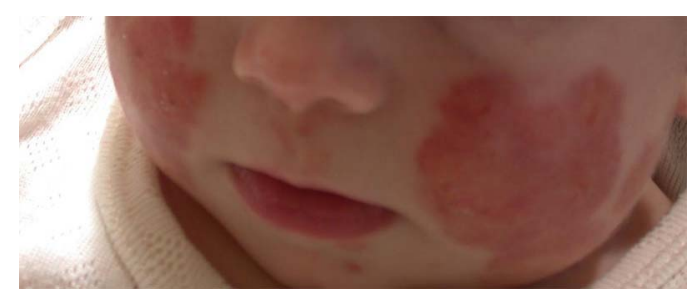

Figure 1 Large purpuric plaques with irregular and annular shapes located in the face.

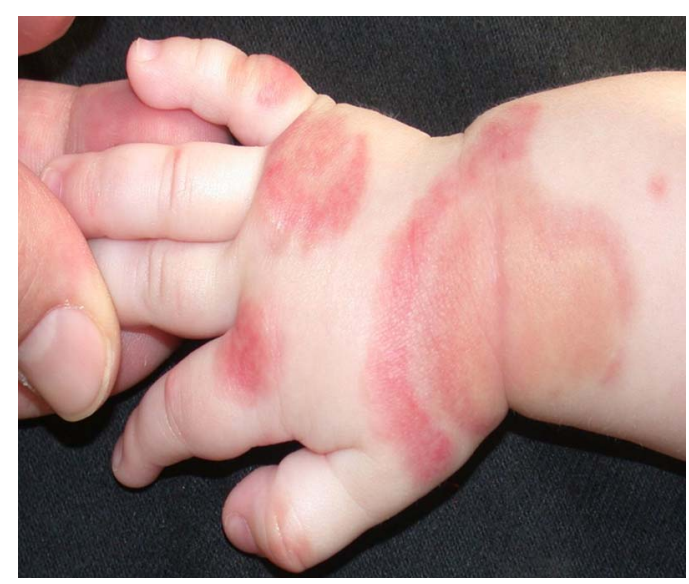

Figure 2 Purpuric plaques with irregular and targetoid shapes in the hand.

Histological findings usually confirm the diagnosis. Treatment is symptomatic. ${ }^{23}$

\section{Learning points}

- Although haemorrhagic oedema of infancy (AHEI) has an alarmingly acute onset, the course is benign and self-limiting.

- The differential diagnosis of AHEI includes meningococcemia; however, patients with meningococcaemia usually are sick-looking.

- Early recognition by physicians should prevent confusion with other more severe conditions.

\section{Competing interests None.}

Patient consent Obtained.

Provenance and peer review Not commissioned; externally pee reviewed.

\section{REFERENCES}

1 Fiore $\mathrm{E}$, Rizzi M, Ragazzi M, et al. Acute hemorrhagic edema of young children (cockade purpura and edema): a case series and systematic review. J Am Acad Dermatol 2008;59:684-95.

2 Fotis L, Nikorelou S, Lariou MS, et al. Acute hemorrhagic edema of infancy: a frightening but benign disease. Clin Pediatr (Phila) 2012;51:391-3.

3 Smitt JH, Vermeer MH, Faber WR, et al. Acute hemorrhagic edema of infancy (AHEI). Clin Dermatol 2002;20:2-3. 
Copyright 2013 BMJ Publishing Group. All rights reserved. For permission to reuse any of this content visit http://group.bmj.com/group/rights-licensing/permissions.

BMJ Case Report Fellows may re-use this article for personal use and teaching without any further permission.

Become a Fellow of BMJ Case Reports today and you can:

- Submit as many cases as you like

- Enjoy fast sympathetic peer review and rapid publication of accepted articles

- Access all the published articles

- Re-use any of the published material for personal use and teaching without further permission

For information on Institutional Fellowships contact consortiasales@bmjgroup.com

Visit casereports.bmj.com for more articles like this and to become a Fellow 